\title{
Donna Haraway (2016) Staying with the Trouble: Making Kin in the Chthulucene. Durham: Duke University Press. 312 pages. ISBN: 978-0822362241
}

\author{
Martha Kenney \\ mkenney@sfsu.edu
}

As a theorist, one of Donna Haraway's central concerns has been to break out from some of the most deadly habits of Euro-American thinking. Her famous "Cyborg Manifesto" was explicitly written as an "ironic political myth" (1991: 149) designed to help us think outside of "the maze of dualisms in which we have explained our bodies and our tools to ourselves" (1991: 181). When we make categorical distinctions between nature and culture, animal and human, organic and artificial, she argues, we fail to grasp how worlds hang together and proliferate specific forms of living and dying. In her new monograph, Staying with the Trouble: Making Kin in the Chthulucene Haraway stages another break-out. Here she takes on a particular kind of dualistic thinking specific to Western environmental thought in the $21^{\text {st }}$ century. On the one hand, we're witnessing unprecedented environmental optimism born of a misplaced trust in technology, the naïve belief in efficacy of "spreading awareness" without really changing anything, and flat-out denial in the face of climate change, species loss, and planet-wide environmental violence experienced predominantly, but by no means only, by the world's poorest people (Nixon, 2011). On the flip side, there is a pervasive eco-apocalyptic cynicism, a feeling that "the game is over, it's too late, there's no sense in trying to make anything any better" (Haraway, 2016: 3). While these positions at first seem opposed, their effects are the same: inaction that does very little except protect the status quo of ongoing environmental violence in advanced capitalism.' Haraway argues that if we want anything to change, we can't afford to dither, throw our hands up, or opt out; we have to enter the fray, "stay with the trouble," and get our hands dirty (even learn to play in the mud!). As feminist science studies scholars like Alexis Shotwell (2016) and Max Liboiron (2016) point out, it's no longer possible to have "clean hands" in a "permanently polluted world" (Liboiron, 2016: 104); purity politics are a no-go. Instead, it is about collectively learning the arts of living on a damaged planet (Tsing, 2015: 292); pushing against complacency, without losing sight of complexities, contradictions, and complicities that come with living in a time characterized by the uneven distribution of wealth and environmental violence.

As in the "Cyborg Manifesto," Haraway's strategy for resisting dualistic environmental thinking is through feminist storytelling. In Staying with the Trouble Haraway spins stories that are mythic, recursive, and looping, stories that repeat central motifs and then spin off on different trajectories. These stories are told in productive tension with recent work gathered around the charismatic concept of 'the Anthropocene.' On the one hand Haraway is sympathetic to the term Anthropocene, recognizing the need for a word that captures the sheer scale of environmental change, such that "any geologist of the future will find the 
synthetic chemistry of DuPont in the composition of the rocks" (Haraway 2015, 259). However, she argues that stories about the Anthropocene often flatten out the politics; when humans-in-general are seen as the agent of environmental change, we don't get at the crucial question of who benefits and who suffers from the environmental practices of transnational corporate capitalism (Haraway, 2016: 49). Haraway offers the 'Capitalocene' as a term that might better account for the uneven economic power and privilege at work in the time Kim Fortun (2012) calls 'late industrialism. But although it offers a more precise diagnosis of the problem, neither the Capitalocene nor the Anthropocene offer a way forward. Staying with the Trouble, then, is the story of something else; it is the story of the Chthulucene. The Chthulucene is the name Haraway uses to gather stories, figures, and practices that might help us to collectively build more livable worlds: "Unlike either the Anthropocene or the Capitalocene, the Chthulucene is made up of ongoing multispecies stories and practices of becoming-with in times that remain at stake, in precarious times, in which the world is not finished and the sky has not fallen yet" (Haraway, 2016: 55).

To conjure the myth of the Chthulucene, Haraway brings motley multispecies stories from different times and places into generative relation with one another as the chapters unfold. In this way, her storytelling practice performs her argument-namely that "a livable world must be composed [collectively] bit by bit, or not at all" (2016: 40). She collects thing up in her net-bag (2016: 118); she thinks sympoietically, ${ }^{2}$ cites exuberantly. Her sources include not only theoretical interlocutors like Isabelle Stengers, Vinciane Despret, Marilyn Strathern, and Anna Tsing, but artists, scientists, her former students, videogames, children's books, web comics, and the work of dozens of projects all over the world that promote multi-species flourishing: The Crochet Coral Reef, Navajo Churro Sheep Project, numerous projects with pigeons including Pigeon Loft in Melbourne where pigeons receive food and shelter, but their eggs are replaced with artificial eggs to reduce their numbers. She writes science fiction about queer interspecies kinship as a response to environmental damage (Chapter 8 ), revels in scien- tific facts about symbiogenesis (2016: 59-68), and spectacularly fabulates about "the chthonic ones," creatures with "tentacles, feelers, digits, cords, whiptales, spider legs, and very unruly hair" that make up the figural substrate of her Chthulucene (2016: 2). "SF worlding" is the name of Haraway's game-telling speculative stories to transform our sense of what is possible. And, as I have been emphasizing, the organization of the book reflects her ontological and aesthetic sensibility-there are no foundations or bottom lines, "it's turtles all the way down" (Haraway, 2008: 32). This is a tentacular, relational kind of storytelling; a generous act of theorizing. Reading Staying with the Trouble, I was reminded of J.G. Ballard's advice to readers of his 1970 novel The Atrocity Exhibition: "Rather than start at the beginning of each chapter, as in a conventional novel, simply turn the pages until a paragraph catches your eye. If the ideas or images seem interesting, scan the nearby paragraphs for anything that resonates in an intriguing way" (Ballard, 2001: vi).

So it's a shaggy book, to be sure. But its shagginess is clearly by design. Haraway has chosen this style of storytelling to cultivate in her readers the capacity for response. At the end of her chapter about the complex histories of the estrogen medications DES and Premarin ${ }^{\oplus}$, which begins with feeding her dog pills for urinary leakage and opens onto stories of DES daughters, German zebras in the 1930, and Pfizer contracted horse ranches in Canada, Haraway writes:

Why tell stories like this, when there are only more and more openings and no bottom lines? Because there are quite definitive response-abilies that are strengthened in such stories. (Haraway, 2016: 115)

Haraway's concept of response-ability (see also Haraway, 2008) is not the liberal humanist obligation to be responsible for one's own choices; rather it is about learning to participate in a collective "praxis of care and response... in ongoing multispecies worlding on a wounded Terra" (2016: 105). The chapters in Staying with the Trouble might best be read as fables of reponse-ability (Kenney, 2013), stories that activate our capacities to attend to and therefore respond within the messy worlds we inhabit every day. They are fables because they 
are didactic; they act on our sensoria; involve us in alternate "economies of attention" (Daston, 2004); initiate us into unfamiliar "arts of noticing" (Tsing, 2016); teach us how to respond and make openings for different types of response. By narrating surprising relations across disparate geographies, temporalities and materialities, Haraway sensitizes us to the ethical and political obligations that these relations demand. If our dogs take DES for urinary leakage, what should we know about the histories of agriculture and big pharma? Haraway argues that we all need to become more curious about the relations that constitute our ways of living, if we want to learn to make worlds that are less deadly for human and non-human others. In her estimation this is "probably still possible. Barely still possible. Still possible if we render each other capable of worlding and reworlding for flourishing" (2016: 96). Storytelling is one practice (among many others!) that can render us capable of responding better "within and as part of the world" (Barad, 2007: 37).

What can we take from such a tentacular, generous, and sympoietic book? Often we look to our best theorists to provide us explanations, terminology, or analytic frameworks that we can apply in our own Science \& Technology Studies (STS) projects. I'd like to suggest that this isn't the only way to approach Staying with the Trouble. It's not that Haraway doesn't offer a compelling theoretical framework for understanding capitalism, environmental violence, and what it might take to enact better worlds; she does. However, it also offers something more important: With her exuberate and omnivorous approach to feminist storytelling, Haraway gives us permission to follow our own curiosities and experiment with our own fables of response-ability. If we believe storytelling is one of the practices that can render us capable of responding to the ravages of the Capitalocene, we will need more stories, not fewer. And not all of these stories will have the same aesthetic and political strategies as Haraway's. Some will be empirical, others imaginative; some haunting and poetic, others no-nonsense practical; some energetic, full of brilliant paradigm-shifting neologisms, others plain spoken and heartfelt. Different kinds of stories engender different ways of attending, responding, and relating. In Staying with the Trouble, Haraway offers important guidance to us, the storytellers of the Chthulucene (i.e. STS scholars); in our own situated projects, we need to ask what it would take to avoid thinking traps of environmental optimism/pessimism, stay with the trouble and imagine ourselves as participants in collective world-making. While the Anthropocene has been useful for gathering the arts, humanities, and social sciences around environmental questions, Donna Haraway's Chthulucene asks us not only diagnose problems but to embrace our roles as technoscientific fabulists and learn to tell stories that strengthen ecological response-ability in a world characterized by ongoing environmental irresponsibility that is both appallingly murderous and spectacularly profitable. 


\section{References}

Ballard J G (2001) The Atrocity Exhibition. London: Flamingo.

Barad K (2007) Meeting the Universe Halfway: Quantum Physics and the Entanglement of Matter and Meaning. Durham: Duke University Press.

Daston L (2004) Taking Note(s). Isis 95(3): 443-448.

Fortun K (2012) Ethnography in Late Industrialism. Cultural Anthropology 27(3): 446-464.

Haraway D (1991) Simians, Cyborgs and Women: The Re-Invention of Nature. New York: Routledge.

Haraway D (2008) When Species Meet. Minneapolis: University of Minnesota Press.

Haraway D (2015) Anthropocene, Capitalocene, Chthulucene. Interview with Martha Kenney. In: Davis H \& Turpin E (eds) Art in the Anthropocene. London: Open Humanities Press, pp. 255-270.

Kenney M (2013) Fables of Attention: Wonder in Feminist Theory and Scientific Practice. PhD Thesis, UC Santa Cruz, USA.

Liboiron M (2016) Redefining Pollution and Action: The Matter of Plastics. Journal of Material Culture 21(1): 87-110.

Nixon R (2011) Slow Violence and the Environmentalism of the Poor. Cambridge: Harvard University Press.

Shotwell A (2016) Against Purity: Living Ethically in Compromised Times. Minneapolis: University of Minnesota Press.

Tsing A L (2015) The Mushroom at the End of the World: On the Possibility of Life in Capitalist Ruins. Princeton: Princeton University Press.

\section{Notes}

1 After science fiction writer Kim Stanley Robinson, Haraway calls our current era of environmental inaction, "The Great Dithering" (144-145).

2 Sympoiesis is Greek for "making together." One of Haraway's central arguments is that everything, including life, is sympoietic. Her citation style reflects an ethical and theoretical commitment to scholarship as something that emerges from ongoing, collective exchange and not sui generis from the minds of great thinkers. 